\title{
LIVELIHOODS IN SCARCITY - COMBINED RAINFED FARMING SYSTEMS IN ISHKAMESH, AFGHANISTAN
}

\author{
STEFAN SCHÜTTE \\ With 4 figures, 1 table and 2 photos \\ Received 18. December 2012 · Accepted 24. May 2013
}

\begin{abstract}
Summary: This paper deals with the multiple insecurities affecting combined rainfed farming systems in the Ishkamesh district of Takhar Province in Northern Afghanistan. It looks at how local natural resource management practices work out under conditions of recurrent and severe drought and how pasture access regimes and rainfed farming practices structure intergroup relations in an area that was affected by heavy fighting during Soviet occupation and civil war in Afghanistan. Based on findings from three periods of fieldwork in the area, Ishkamesh can be used to provide a better understanding of practices of rainfed agriculture and the construction of rural livelihoods at the Afghan periphery, which is influenced by high risk environmental conditions. Affected by scarcity of land, deficiency of water, restricted income opportunities and restricted access to education and health facilities, the threats to human security of local populations are identified and security strategies examined.
\end{abstract}

Zusammenfassung: Afghanische Bauern sind in vielfältige landwirtschaftliche Produktionssysteme eingebunden, doch nur sehr wenige Haushalte können durch ihre landwirtschaftliche Tätigkeit wirtschaftliche Unabhängigkeit und Selbstversorgung erzielen. Dies gilt insbesondere für die peripheren Regenfeldbaugebiete in den Gebirgsregionen des Landes, die von geringer Anbaudiversität gekennzeichnet und besonders anfällig gegenüber wiederkehrenden Dürreereignissen sind. Das Beispiel des am Hindukush gelegenen Distrikts Ishkamesh in der nordöstlichen Provinz Takhar soll herangezogen werden, um die multiplen Unsicherheiten der ansässigen Bevölkerung genauer in den Blick zu nehmen. Dabei stehen Fragen nach den existierenden Bedrohungen, Konflikten und alltäglichen Unsicherheiten und nach den „Sicherheitsstrategien“" unterschiedlicher Bevölkerungsgruppen und Haushalte im Vordergrund. Die Analyse basiert auf drei Feldforschungsaufenthalten in der Region und fokussiert auf die Situation in ausgewählten Dorfgemeinschaften und den Beziehungen zwischen verschiedenen sozialen Gruppen. Das Beispiel Ishkamesh repräsentiert dabei ein besonders geeignetes Fallbeispiel, um die Praxis von Regenfeldbausystemen und ländlicher Lebenssicherung in der afghanischen Peripherie unter Bedingungen einer risikoreichen Umwelt, des limitierten und konfliktbehafteten Zugangs zu natürlichen Ressourcen und von politischer Instabilität besser zu verstehen.

Keywords: Afghanistan, rainfed agriculture, drought, pasture management, human security

\section{Introduction}

Afghan farmers aim to achieve livelihood security within a wide diversity of agricultural systems and production conditions. However, while different forms of farming combined with practices of animal husbandry represent the major livelihood strategies of rural Afghans, there are only few households that command the resources necessary to achieve subsistence and self-sufficiency (RoE 2009). The necessity to generate further monetary incomes affects most of the Afghan rural population (GRACE and PAIN 2004). This is true for irrigated agriculture in the fertile river oases of the country, but even more so for rural communities in remote mountain locations with low crop diversity who fully depend on rainfed agriculture and have constrained access to off-farm incomes. Similarly, recent studies on Afghan farming systems revealed that households with irrigated farms persistently demonstrated the strongest asset portfolio, whereas rainfed farmers were the most asset-poor and most vulnerable among agro-ecological groups in Afghanistan (Roe 2008; Flaming and RoE 2009).

The present article aims to deepen the understanding about the functioning of combined rainfed farming systems and the multiple insecurities to which they are exposed. Focusing on a village community and intergroup relations in the District of Ishkamesh in the Northern Afghan Province of Takhar (Fig. 1), this article aims to demonstrate how Afghan rainfed mountain farmers manage to con- 


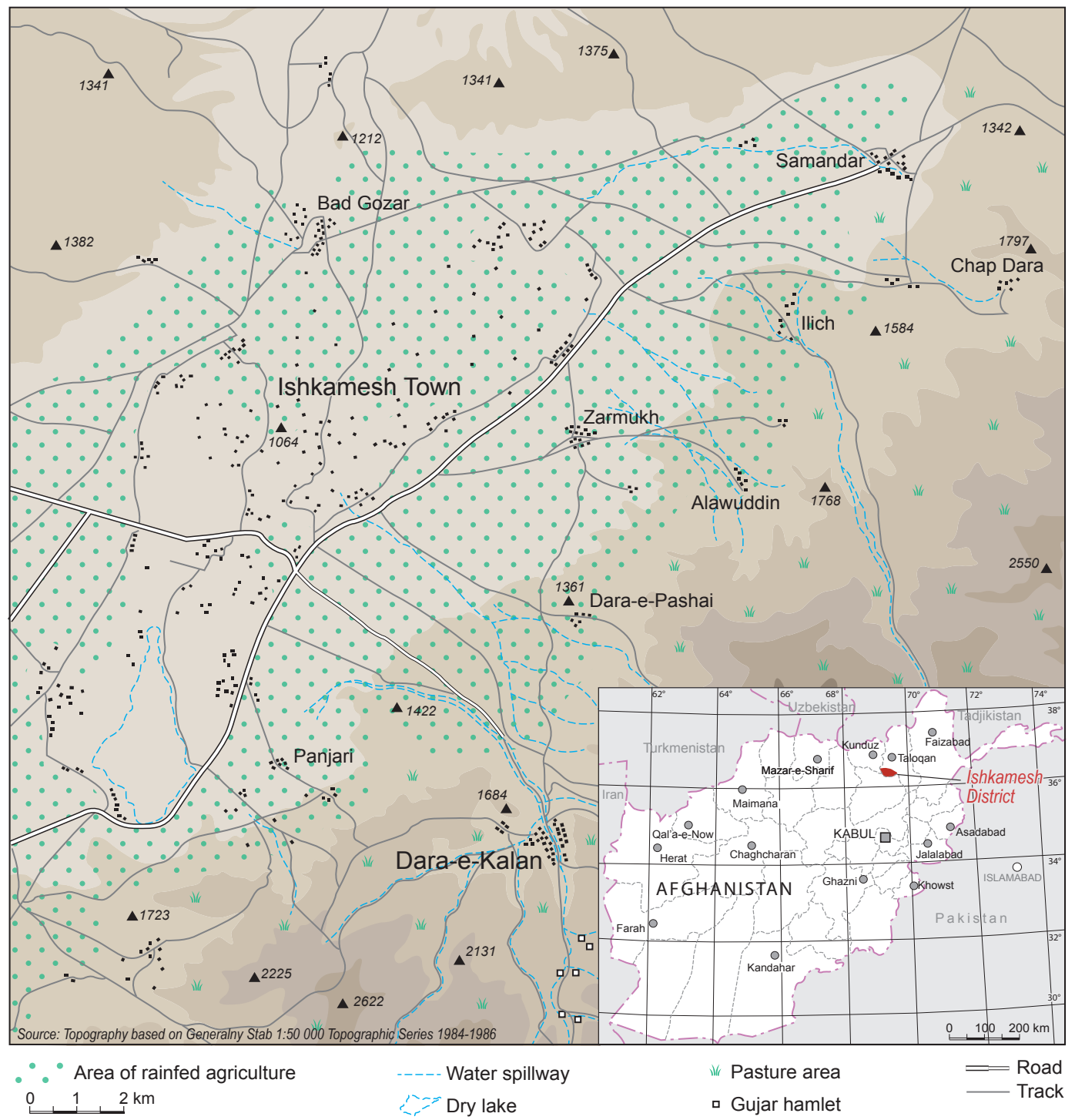

Fig. 1: Location of the town of Ishkamesh and surrounding villages

struct their livelihoods in high-risk environments with limited access to key natural resources that influence both agricultural production and livelihood decision-making.

In doing so, the study employs a human security perspective on social vulnerability. The term is used here in contrast to the widespread denotation of human security as a contentious policy and governance tool located at the nexus of development and security. It is often used to define the social and economic problems of underdevelopment as dangerous and a threat to the global order (Duffield 2001; BEEBE and KALDOR 2010). In Afghanistan, such use of the term in development policy led to the emergence of development-based counter-insurgency measures under control of the international military (Zitelmann 2011). Furthermore, through its integration into securitization agendas of the North and the attendant collusion of development practice with military and political powers, it exerts significant political pressure on humanitarianism (DONINI 2007; WeIZMAn 2011).

Quite contrary to such policy considerations in the 'humanitarian present' (Weizman 2011), human security is deployed here as an analytical framework that focuses on human agency and people's capabilities (BoHLE 2007). As a conceptual approach, the term has been defined in various contested and not always coherent ways, and its applicability highly criticised (Paris 2001; King and Murray 2001). At 
the same time, questions of how to measure human security have come under scrutiny (Owen 2003). The focus of development research in the application of the concept has usually been placed on safety, freedom, rights, and capabilities while building on and adapting the original definition put forward by the UN (UNDP 1994).

Given these wide and contested receptions of the human security framework, the view advocated here to describe the Afghan case study in Ishkamesh aims to establish a clear operationalization of the concept along three major lines that correspond to the original UN definition and build on the prevalent criticisms. Such an understanding of human security looks at:

- Livelihood security strategies and how people manage their lives in a context of vulnerability. This perspective aims to assess what room for manoeuvre is available to Afghans when managing their livelihoods. For the case of Ishkamesh, the analytical focus is on practices of agricultural production and animal husbandry.

- Risk management and conflict resolution strategies and how people aim to mitigate exposure to threats. This perspective examines existing threats to livelihood security, prevalent conflicts, and ways to deal with livelihood risks. For the present case, this leads to analysing intergroup relations and social inequalities, practices of local resource management and the structure of land access regimes in Ishkamesh.

- Empowerment and how people strive to live a life with dignity and self-determination. This perspective looks at people's capabilities and the attainable opportunities that are available to them. In the present case study, this perspective is important when examining the work of local institutions in the study area.

The article begins by establishing the empirical and methodical basis of the case study before elaborating on the recent and changeful history of the study area and its social setup. Subsequently, the multiple insecurities affecting lives and livelihoods in the area are identified and the 'security strategies' people employ to manage uncertainty examined.

\section{Methodology: assessing human security in Ishkamesh}

Findings presented in this article are based on three field visits to the Ishkamesh area between 2007 and 2009, during which three focus groups and open individual interviews were held with mountain farmers who combine agricultural production with animal husbandry in the village of Dara-e Kalan (Fig. 1), and open interviews with landless pastoral groups (Gujar) engaged in mobile livestock keeping who live in the village surroundings. The focus groups consisted of members of the local community council (shura) and included influential persons such as the village headman (arbab), the religious dignitary (mullab), teachers and respected elders, but also common village residents engaging in rainfed agriculture and animal husbandry as well as persons belonging to landless households. Pastoral Gujar were interviewed when encountered during area walks. In addition, the natural resource basis and land use systems of the mountain village were assessed and mapped. Cursory evidence gathered through group discussions in additional village settlements was used for further illustration. Interviews and focus groups were guided by focusing on the three analytical perspectives on human security as outlined above. However, limitations apply as it was not made possible to talk to women in the community and directly explore their roles in agriculture and animal husbandry (cf. GRACE 2004).

This case study is presented here to better understand practices of rainfed agriculture and combined mountain farming in the Afghan periphery that is influenced by high risk environmental conditions and unstable political conditions. Moreover, the study area is subject to scarcity of land, deficiency of water, restricted income opportunities and restricted access to education and health facilities, which pose threats to the human security of local populations. In addition, it provides an example as to how the complicated land tenure relations in Afghanistan (cf. ALDEN Wily 2003; McEwen and WhitTy 2006; Maletta 2007) work out in everyday practice.

\section{Ishkamesh: social spaces and historical precedents}

Recent history in Ishkamesh has been characterised by high levels of violence and conflict-ridden intergroup relations. The area is populated by different social groups of mainly Tajik affiliations, but also sizeable clans of Uzbek and Pashai origins. These broader ethnic groupings are locally segmented and form various endogamous qaum that make up complete and socially homogeneous village communities in Ishkamesh. The qaum as fundamental social units, though often not precisely defined by Afghans them- 
selves, can be designated as an essential marker of social identity in Afghanistan and represents the basic solidarity group that aims to protect its members against external encroachments, facilitate shared work for the common good and establish self-help systems in times of crisis (cf. SHahrani 1986, 24; Roy 1989, 71; 1990, 26; Glatzer 2001). In the case of Ishkamesh, it also governs local natural resource management and access systems for rainfed agricultural land and common pasturage.

These various groups and their qaum are the established settlers in the area that are mostly engaged in practices of combined mountain agriculture, thereby making seasonal use of different ecological zones for agriculture and animal husbandry (EHLERs and KreutZmann 2000). However, there is also the social group of the Gujar who reside in scattered hamlets at higher altitudes. Gujar are more recent arrivals in the area who presumably migrated from Kunar and Nuristan to Ishkamesh only some 20 to 30 years ago and maintain links to the Chitral region of Pakistan (BALland 1988; GrötZBACH 1990). Gujar practice animal husbandry and encroach on common natural resources and were therefore viewed with suspicion by established groups right from the beginning. As latecomers in an already populated area, territorial competition led to a marginalized and precarious social and economic position in the social setup of Ishkamesh, a fact that holds true for Gujar groupings all over the Hindu Kush region (BARTH 1956; Balland 1988; Dhirendra DatT 1997). However, the case of Ishkamesh is especially delicate as Gujar were involved in armed conflict against the other groups during the violent upheavals of the 1990s that left permanent marks on intergroup relations.

Before the civil war, Ishkamesh served as a major Mujahidin stronghold during the resistance against Soviet occupation and was exposed to severe aerial bombardments and high levels of destruction (Grau and Cress 2002, 119-122). Study villages were completely destroyed by Soviet helicopters and residents either joined the resistance or fled the country. After the civil war, the advance of the Taliban during the mid-nineties led to another peak of violence and heavy fighting between Taliban fighters and members of the so-called Northern alliance that established strong support in the area. The Taliban advance was stopped eventually but led to lasting grievances between different residential communities who fought on different sides during the armed conflict. The majority of Tajik and Uzbek groupings supported by the resident Pashai opposed the Taliban that aimed to ensure local support by en- rolling the local Gujar community as mercenaries for their cause. The matter is a delicate one because all groups that were involved in past upheavals need to co-exist in a continuum of conflict over scarce resources and cooperation for mutual benefit today.

The resulting social economy is characterized by social inequalities where the landed Tajik, Uzbek and Pashai communities engage in rainfed agricultural production that is highly vulnerable to drought conditions. This is combined with practices of animal husbandry seasonally utilising high altitude mountain pastures in the environs of village settlements. Gujar profit from their reputation as renowned experts in animal husbandry but have no access to agricultural land at all. Their reputation as experts in raising goat and sheep extends over the entire Hindu Kush region and makes them sought after shepherds who are employed on a seasonal contract basis. However, their marginal social position and their history as Taliban fighters is cause for distrust and repeated conflict over the use of natural resources.

Against this backdrop, multiple resource use strategies are in place. The modes of pasture usage as practised in the area are subject to precise and shared regulations of customary law that set limitations on pasture access and structure intergroup relations in many important aspects.

Supplemented by remittances generated out of male wage labour migration, predominantly to Iran and major Afghan cities, combined mountain agriculture provides the background for the prevalent strategies of natural resource management in Ishkamesh in the face of multiple insecurities affecting life and livelihoods. The following account identifies these insecurities and illustrates which livelihood strategies people employ to manage uncertainty (cf. Tab. 1).

\section{Drought conditions, scarcity of water, and water conflicts}

While the protracting war conditions in Afghanistan and its image as a failed state dominate the media and much of the scientific coverage of the country, the multifaceted problems of natural resource management and the economics of rainfed farming receive only scant attention. This is all the more astonishing as environmental conditions in the country often turn out to be a constraining factor in the establishment of rural livelihood security, both viewed through the eyes of affected communities themselves and development agencies aiming to 
Tab. 1: Multiple insecurities and security strategies in Ishkamesh

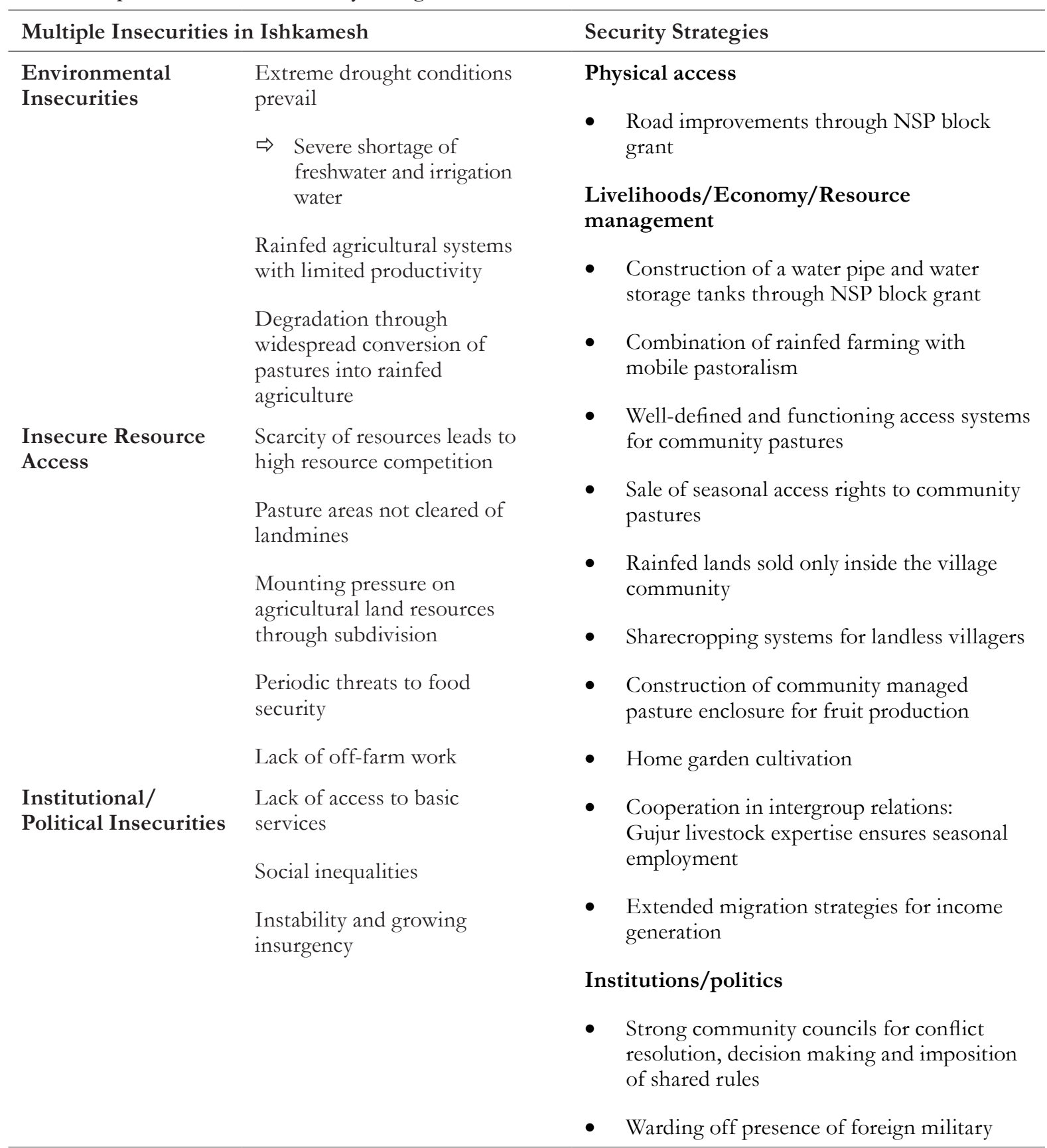

support agricultural production (LAUTZE et al. 2002). The saying of one villager that "one year of good rain and snow is much more effective than ten years of development aid"1) illustrates this vital truth and the actually existing problems of drought conditions and water scarcity that threaten the livelihoods of the rural poor in Afghanistan. Looking at the hard

\footnotetext{
1) Recorded during a group interview in autumn 2007.
}

facts uncovered by new satellite-based drought monitoring systems that use data on vegetation stress also reveals a very difficult picture, with severe and exceptional drought conditions frequently having held sway over more than half of Afghanistan in the last decades. A peak was reached in 2001 after three years of consecutive drought when almost 90 per cent of the entire country was affected by severe drought conditions (Kogan 2002). This led to high 
levels of displacement when people abandoned their homes in search of food and water, and increased dependencies on foreign food aid (GERSTLE 2004). Even more so, the Afghan people apparently witnessed the most severe drought in living memory in 2008 (Savage et al. 2009). Such conditions also pose problems for irrigated agriculture as practiced in the fertile river oases of Afghanistan, when canal water becomes scarce and its distribution contested. However, for the rainfed areas in the North-eastern parts of the country or the central highlands, such conditions pose major threats to the lives and livelihoods of farmers when crop losses occur. Under the conditions of global warming and the effects of a noticeable climate change in the Hindu Kush-Himalaya mountain ranges, those long spells of drought are likely to continue with severe stress on water resources and water availability (AFGHANISTAN HUMAN DEVELOPMENT REPORT 2011; AKHTAR et al. 2008; Savage et al. 2009). Thus it is to be expected that the comparatively low productivity of rainfed farming will be even more exacerbated in future.

The District of Ishkamesh is such an area where the entire agricultural activity is based on rainfed farming under conditions of severe water shortage (GrötZBACH 1990, 266ff.). Groundwater resources are scarce and difficult to access, and surface water storage and collection fully depends on sufficient amounts of rain and snowfall. Here, the very frequent drought conditions require balanced adaptation and risk management strategies along with careful managing of limited natural resources. As one local respondent remarked: "all things in Ishkamesh depend on water - when there is no water, then there is no life". 2)

Scarcity of water already leads to water competition between villages and social groups and the emergence of water conflicts. In an area where scarce mountain springs provide the sole means of access to drinking water there have been incidences of conflicts over access, which in one reported case has already led to the destruction of a mountain spring, which before the conflict had supplied an entire village community in the settlement of Ilich. As a result, this community now depends on establishing water access from a distant spring belonging to the neighbouring village of Chap Dara (cf. Fig. 1).

The pattern of village locations in Ishkamesh bears witness to the scarceness of water in the area. Settlements are not located close to agricultural fields as is customary in mountain oases, but locations have

\footnotetext{
2) Recorded during a group interview in autumn 2007.
}

been chosen that make daily mobility to mountain springs less strenuous. The recent activities implemented through the National Solidarity Programme (Nixon 2008; Beath et al. 2010) have somewhat dissolved tensions in Dara-e Kalan through the construction of village-based pipe and storage systems that established a connection between mountain springs and the settlement and significantly reduced mobility efforts and surface contamination, ${ }^{3)}$ but intergroup relations are still sensitive to water scarcity. Especially the recent advent of Gujar communities in the vicinity of the settlement has led to recurrent frictions, as established groups begrudge Gujar using the same resources and tapping off from what are perceived as own water resources. At the village level, however, limited use of water for garden irrigation is permitted, given sufficient rain or snowfall. In Dara-e Kalan, a simple surface canal network is connected to the newly constructed pipe system and controlled by two 'water masters' (Mir Ab), i.e., elected and accountable persons governing irrigation water distribution to individual households (cf. THOMAs and Ahmad 2009). In good years, this allows for cultivation of vegetables and fruit trees in private gardens. During the recent droughts, however, garden irrigation has not been an option in Dara-e Kalan. In spite of the severe drought conditions governing the lives of people, villages are regularly exposed to flood risks during the snow-melt that constitute the Afghan water paradox of alternating droughts and floods (Beekma and Fiddes 2011). In Dara-e Kalan, the effects of frequent exposure to excess water in a drought prone area are clearly visible, and the village is literally cut in half by a water spillway that is lined by peoples' residences (cf. Fig. 2).

\section{Vulnerability of rainfed farming systems}

Rainfed agriculture (lalmi) represents a vital element of economic activities in the combined mountain agriculture of Ishkamesh. This is also the case for Takhar Province as a whole, where rainfed farming - which had a share of about 80 per cent of all agricultural activity before the Soviet occupation (cf. GrötZBACH 1990, 105) - represents the dominant form of agricultural production in an area constrained by an overall limited availability of arable lands. The somewhat uniform cropping pat-

3) Another part of the block grant was used to repair the link road to the village, making access to Ishkamesh town easier, especially during winter. 


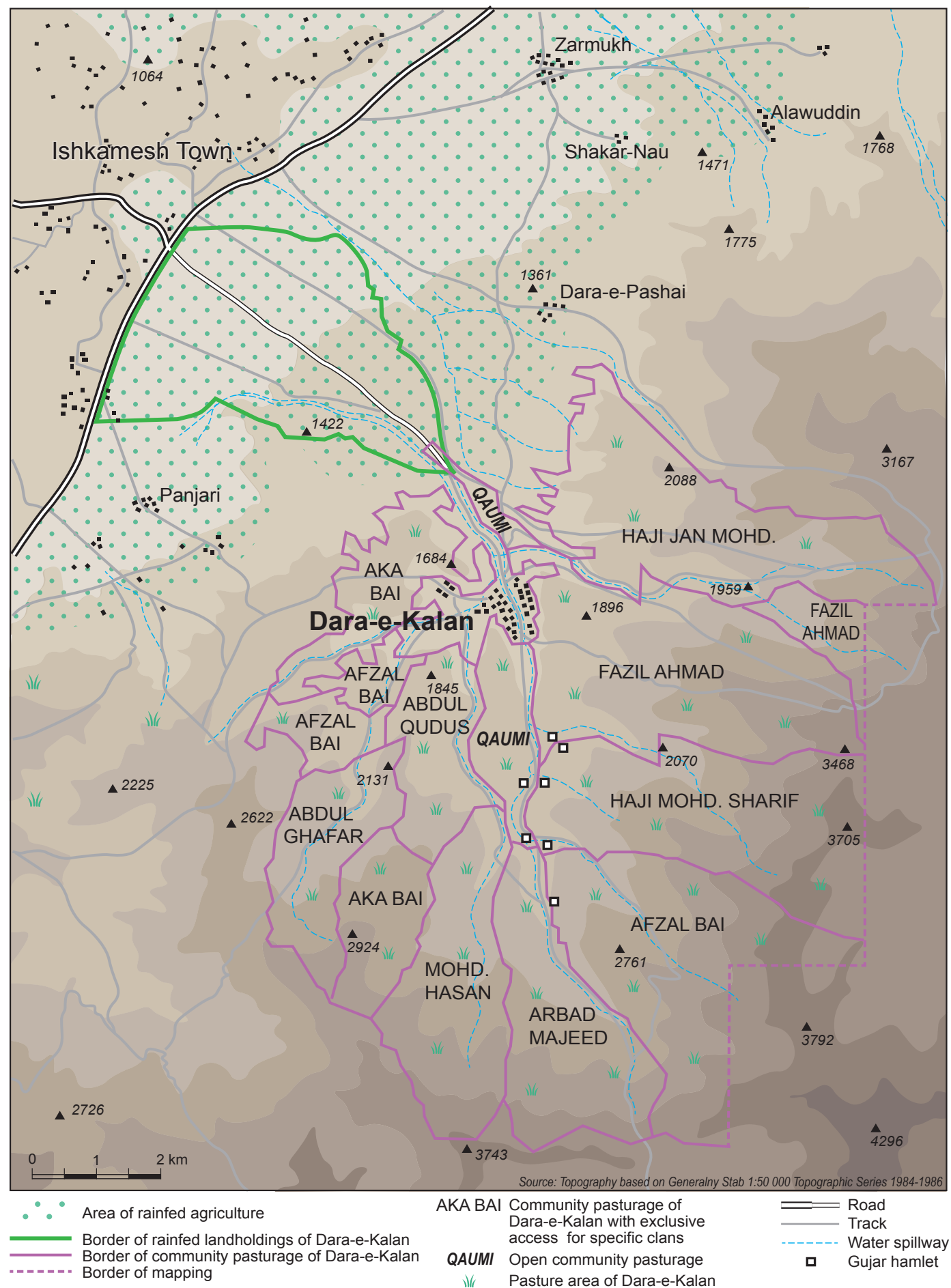

Fig. 2: The local resource system of Dara-e Kalan village showing the location of its rainfed landholdings and the areas of community pasturage that were mapped together with villagers. The names of clan chiefs in refer to the holders of access rights to defined pasture areas over a certain period. Note that the boundaries of the eastern parcels of pastureland belonging to Dara-e Kalan have not been defined exactly, as illustrated through the dotted line 
tern on rainfed landholdings that is largely restricted to wheat production holds true for Ishkamesh too, where wheat represents the single staple crop. Looking more closely at the case of Dara-e Kalan, a number of observations on the vulnerability of rainfed farming systems can be put forward that bear relevance for the entire district.

The village Dara-e Kalan is inhabited by 342 households that refer to themselves as Tajik belonging to the qaum of Gudri. These households form a village population of about 3,000 people, according to the local community council (shura) that has been elected through the National Solidarity Programme process. Most of the elected shura members belong to the more powerful and influential strata of village society, a fact that reflects the tendency of villagers to choose those persons as their leaders who have proved experienced in dealing with authorities and who have held leadership positions in the past. As such, the social institution of the shura in Dara-e Kalan as a newly elected body is effectively the same as the traditional village council embodying the customary way of community representation in Afghan villages.) Cursory interviews with ordinary villagers revealed that the shura is indeed seen as viable representation of the common interest, and its regulative and organisational capacity in terms of natural resource management and conflict resolution appears to be widely respected and affirmed. However, no council of women has been established through the NSP that would potentially provide a forum where women could make themselves heard more prominently.

Social stratification in the village is defined by land and herd ownership, and it was estimated during focus groups that about $30 \%$ of households have both landed property and livestock, and 10\% access only to small land parcels. The majority of villagers thus work as sharecroppers and households rely on labour migration. This pattern of landownership has significantly changed over the last generation, as can be seen through a closer examination of the cadastral survey data for the village.

The village agricultural lands were surveyed and mapped by the Cadastral Survey as a line department of the Afghan Geodesy and Cartography

4) NSP-elected community development councils and the customary shura cannot always be regarded as one and the same. In many Afghan villages, the elected councils and traditional shura appear to exist side by side, but in some respects with separate agendas and different groups of people involved.
Head Office (AGCHO) in the year 1975 (cf. Fig. 3). The records held in the Cadastral Survey Directorate in the provincial capital Taloqan are the only available official recordings about ownership patterns of land today that were to be used for the purpose of collecting tax and tithing and were established for about 45 per cent of Takhar Province. This comprehensive trigonometric mapping of land parcels and the gathering of information about the ownership of each of the mapped land parcels was to be the basis of a new system of land registration as well as an inventory of land resources for property taxation and program planning, until Soviet occupation and civil war put an end to such efforts (STANFiELD 2007). Today, the cadastral survey recordings that were established for about 34 per cent of all agricultural lands in Afghanistan represent an invaluable record of land use patterns, land classification and the location of parcel boundaries that now can be used to assess changes in land relations that have occurred over time.

The land holdings for the village of Dara-e Kalan are located some distance away from the main settlement (cf. Fig. 2). According to cadastral survey data of 1975, the entire rainfed area of the village amounts to 10,116 jerib (ca. 2,023 ha) on altogether 721 bounded land parcels, with a median holding size of 11.4 jerib (ca. $2.3 \mathrm{ha}$ ). ${ }^{5}$ ) This corresponds to the general observation that across the board rainfed holdings tend to be larger than individual land parcels in irrigation areas (Roe 2008), but is significantly less than what has been reported as the average size for landholdings in Takhar Province (45 to 65 jerib in 1968, cf. GrÖTZBACH 1990, 94). The cadastral data also shows that 260 households in the village shared the 721 parcels of registered lands in 1975 . Not a single woman is listed as a landowner in the survey lists, pointing to the gendered inequalities of resource access at the village level. ${ }^{6}$ Individual landholdings are more often than not small individual parcels, with 128 households having access to multiple plots. This is important in view of the current situation more than 35 years after the cadastral survey was carried out in Ishkamesh, and the subsequent impact of

\footnotetext{
5) Data accessed at the cadastral department in Taloqan, November 2006.

6) Gender roles in Afghan agriculture are more generally defined by lack of ownership of the majority of productive assets by women. Even when diversity applies in terms of age, marital status or household wellbeing, women generally appear to seldom have a full ownership right to land that is mostly passed onto their sons or male relatives (GRACE 2004).
} 


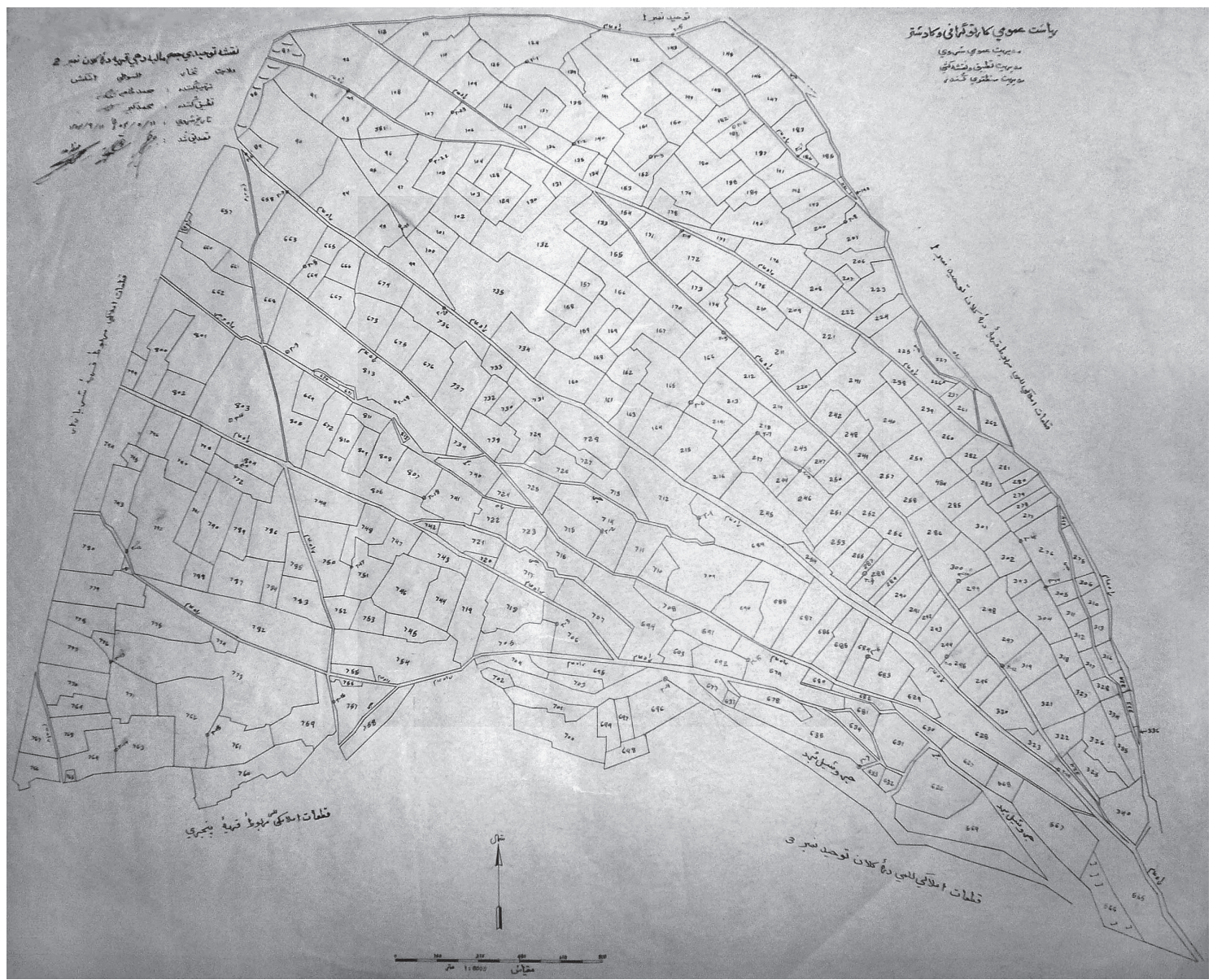

Fig. 3: Cadastral survey map of the entire landholdings for Dara-e Kalan. Photographed in the Provincial Cadastral Survey Directorate in Taloqan, Takhar, on November 11, 2006

continuous subdivision of agricultural land parcels through legal succession.

As is the case for a majority of rainfed farming households all over Northern Afghanistan (KUGBEI 2011), people do not use any fertilizer apart from animal droppings emanating from the small flocks of sheep and goat that are allowed to feed on crop residue after the autumn harvest. With harvests being constrained by eco-hydrological challenges in an inherently vulnerable ecosystem subject to water scarcity, investments in fertilizer to increase wheat yields do not appear rational.

Limited productivity of rainfed agriculture in Ishkamesh but also elsewhere in Afghanistan (cf. JeNTsCH 1973) leads to the fact that harvest outcomes never suffice for complete subsistence. This is true even on larger landholdings and in favourable years. Thus, annual household food requirements can never be met and need to be supplemented from the market. In the case of Dara-e Kalan village, this poses a problem for many households without access to different sources of income. In good years, people expect that for each kilogramme of planted seed, roughly three kilogrammes of wheat can be harvested. These, even under favourable conditions, very low ratios have not been achieved in recent times, and during the drought of 2008 they dropped significantly so that in many instances one kilogramme of seed input yielded only one kilogramme of wheat as was reported for the village of Dara-e Kalan. The drought of 2011 was even worse, and many households all over NorthEast Afghanistan lost their entire harvest resulting in critical degrees of food insecurity (IRIN 2011). These adverse production conditions for rainfed farming in Ishkamesh leads to the fact that migrational strategies are very pronounced, and virtually every household in Dara-e Kalan has a male person working in Iran, Pakistan, or an Afghan urban centre, making remittances a significant ingredient to household livelihood portfolios in rainfed farming systems. 
However, in spite of its meagre productivity, land represents status, and landed property infers a sense of belonging and is a marker of social identity. This is why land is by all means kept inside the village community. When for some reason a person is forced to sell a plot of land, a direct neighbour to that specific parcel has the customary right to purchase it. Only when the owner of a neighbouring parcel is in no capacity to do so, does another person from the village have the right to purchase the land in order to keep ownership of the valuable resource inside the village community. This is why the boundaries of Dara-e Kalan rainfed lands have remained the same as were delineated through the cadastral survey in 1975 and the absolute arable land area of Dara-e Kalan has not changed (cf. Figs. 2 and 3). However, fewer households have direct access to agricultural land today because individual plot-sizes have gradually decreased through subdivision between legal heirs after successive rounds of inheritance. This tendency can be observed when comparing parcel sizes in the cadastral mapping of 1975 with parcel boundaries in recent satellite imagery. The changing boundaries of individual land plots indicate how landholdings were subdivided over time, contributing to a growing scarcity of viable rainfed lands when smaller productive areas have to feed a growing population (cf. Fig. 4).

However, in spite of an increased subdivision of land parcels, it was estimated by villagers that today only about $40 \%$ of households in Dara-e Kalan have access to own agricultural land, which is considerably less than documented through the cadastre in 1975. Village respondents accounted for this growing landlessness and divide in land ownership patterns through two concurrent developments that occurred during the recent past.

First, growing displacement during Soviet rule and civil war led many people to sell their land before taking refuge in safer areas. Second, the need for cash resources had many households seeking credit through specific practices of mortgaging (geravi) where land is used as collateral. The practice entails that people transfer all rights of use to the person providing the cash. The original owners retrieve their right to the land only when the loan is paid back. This is a risky undertaking, and many households reportedly lost their agricultural plots in this way because they were not able to repay the mortgaging debt.

Together, these developments led to a growing number of farming households in the village that are contracted by landowners and engage in sharecrop-

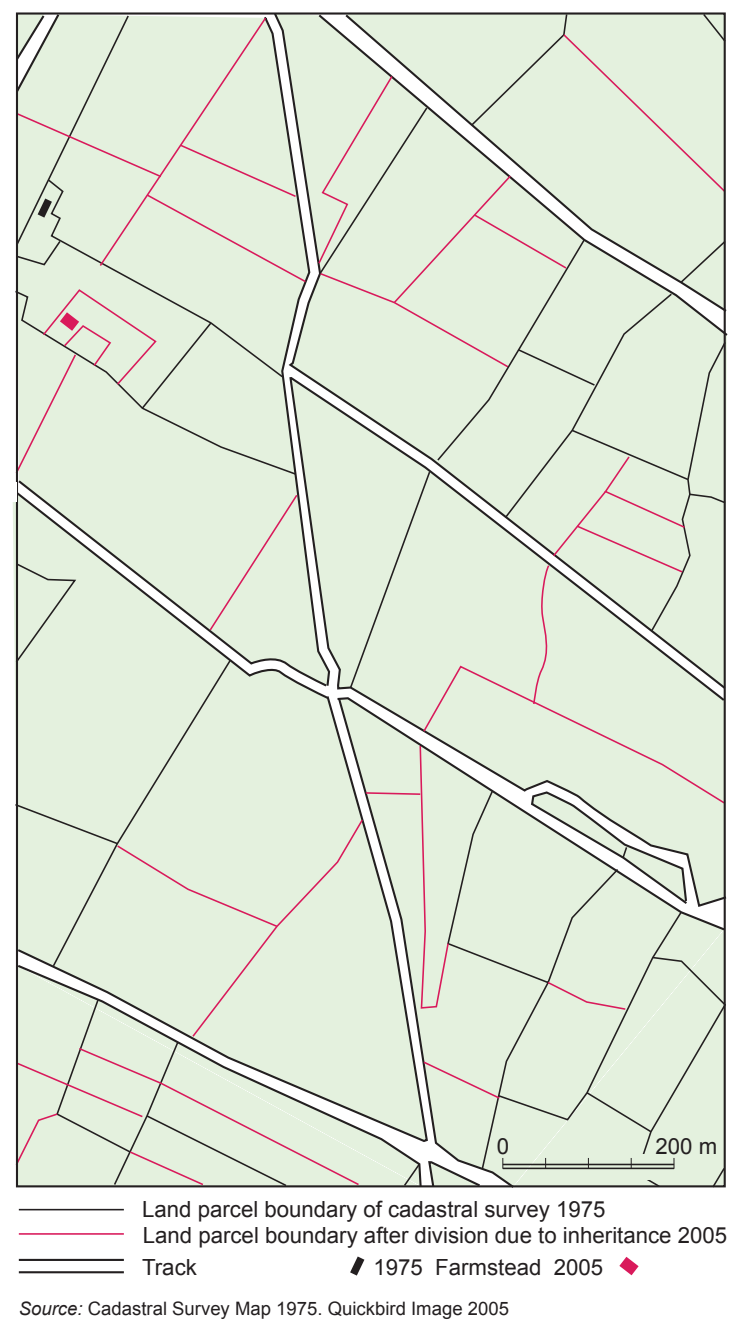

Fig. 4: Changes over one generation: comparison of parcel boundaries between cadastral survey data from 1975 and satellite imagery from 2005 showing the advancing subdivision of rainfed land parcels through successive rounds of inheritance

ping activities. In Dara-e Kalan, there are two forms of sharecropping agreements that represent an opportunity for landless but skilled farmers to access agricultural land: Either a landowner simply rents out his plot for a $1 / 3$ share of the produce, or in an alternate form, owners supply the seeds and then the produce is shared on a 50/50 basis with the actual farmer.

Looking at the structure of the low-productivity rainfed farming system of Dara-e Kalan, it becomes obvious that climatic variability and recurrent drought conditions pose serious problems that regularly endanger the food security of local populations. This is not really a new observation (cf. RATHJENS 1975) and it is therefore all the more astonishing 
that the international aid machinery has largely neglected the problems of rainfed agriculture. These could potentially be improved through what has been described as 'vapour shift' and 'crop per drop' improvements in rainfed farming (cf. ROCKSTRÖM 2003). The existence of certain sharecropping practices that enable landless farmers to access agricultural produce, the interlocking of rainfed farming with animal husbandry, and the selling of land only inside the own community to foster group solidarity represent some strategies in dealing with growing insecurities. However, there is mounting pressure on agricultural land resources that can only be partly addressed through additional social and economic strategies such as labour migration and pastoralism. Still, pastoral strategies are the second major component of livelihood strategies and combined mountain agriculture in Ishkamesh, and it is in these pastoral practices that local intergroup relations and, more generally, the broader issues of land relations become most visible.

\section{Animal husbandry, pasture relations and pasture management in Ishkamesh}

Pasture relations and pasture management in Afghanistan have generated more scholarly attention than the practices and constraints of rainfed agriculture, mainly focusing on the manifold problems of land grabbing and the diverse practices of nomadic pastoralism (JENTSCH 1973; BARFIELD 1978; GLATZER 1981; Alden Wily 2004; Kreutzmann and Schütte 2011; SCHÜTTE 2012). Up to seventy percent of the country is used for grazing or for the harvesting of bushes for animal fodder or fuel, but access to certain pastures is heavily contested and often the source of volatile conflict nowadays (ALDEN WILY 2004). The massive problems of pasture relations have also prompted the Government of Afghanistan to address the issues in its Land Policy document that was approved by cabinet in 2007: "The competition for limited resources of pasture in many areas in Afghanistan has adversely affected the economic livelihood of pastoralists and fuelled long standing conflicts. The competition over grazing land between pastoralists and settled farmers is a result of [...] poor land management, lack of adequate land survey, the non-existence of adequate dispute resolution mechanisms, the near collapse of land adjudication and registration systems, and the lack of strict enforcement of existing laws. The lack of adequate management and control over public owned land has resulted in grabbing of land that was traditionally used by pastoralists as well as settled farmers for grazing livestock herds. The regulation of pasture land is an imperative if it is to be protected from threats to its sustainable use such as illegal grabbing of community lands of neighbouring villages, grabbing of rangeland, cultivation of traditional grazing land, government designation of grazing rights in what have traditionally been considered communal grazing lands. Pastoral ownership is unclear and formal law ambivalent as to whether pasture lands are state-owned, public or communal" (Section 2.2.6 of the Land Policy of Afghanistan, GoA 2007).

This passage identifies the major problems affecting Afghan pasturelands, including those of Ishkamesh, but solutions to these problems need yet to be devised and implemented. Localised customary practices of pasture regulation appear to be rather widespread and work as shared natural resource management strategies, and the example of Dara-e Kalan in Ishkamesh serves as a case in point. More generally and in a process oriented and decentralised view to pasture management, there have been recent attempts to establish localised and community-based land administration systems that aim to develop village communities into the basic land administration body of the country in a staged approach, thereby building on customary social practices as the very basis to resolve pasture conflicts (cf. ASIAN DEVELOPMENT BANK 2008; AldEN WiLY 2009).

Governed by the local shura, an explicit pasture access regime is upheld that is strictly observed by all potential users and user groups of Dara-e Kalan village pastures. Evidence suggests that similar systems are upheld in neighbouring villages too, eventually encompassing the entire pasturage around the township of Ishkamesh and possibly the whole district. Formally, the provisions of the Pasture Law of Afghanistan (GoA 2000) apply that was last amended under Taliban rule. The law distinguishes between areas of specific pasture (alafchar-e khas) and public pasture (alafchar-e aam). Customarily referred to as 'maraa', specific pastures are those where inhabitants of adjacent villages are provided with exclusive user rights. Public pastures are for public use but according to the law fall under government control. However, boundaries between such public and community pasture areas are not recorded anywhere in the appropriate governmental agencies. Local resource management practices that apply to villages in Ishkamesh refer to those areas that are deemed as 'maraa'. 
Consequently, the user rights to these pastures are exercised by villagers and controlled by the community council. In practice, the access regime works in a rather sophisticated way that establishes clear and unanimous boundaries of certain pockets of pasturelands, which belong to specific and extended clan groups that practice animal husbandry; together these make up the village community of Dara-e Kalan. Each of these clan groups stems from a common ancestor who was an original dweller of the village. Altogether, there were nine such clan groups in Dara-e Kalan, each of them endowed with the exclusive seasonal right over specific and clearly bounded parcels of mountain pastures in the vicinity of the village (Fig. 2). Those clans that possessed larger amounts of livestock established access to multiple bounded pasture areas, which in some cases and over time were subdivided to accommodate extended progeny but are still referred to with the name of a common ancestor (Fig. 2). The boundaries of these pasture pockets are unanimously agreed upon between village clans as well with neighbouring village groups.

Exclusivity of access rights essentially refers to the fertile spring season from March to May, when grass is abundant after sufficient rains. During the rest of the year when pasture resources are limited, everybody is free to use all village pastures. In addition to these clan-pastures, there are two separate areas referred to as qaumi. These are pastures that can be used by all villagers all year round and are located in the immediate and more easily accessible surroundings of the village (cf. Fig. 2).

With exclusivity of pasture access in the fertile season also comes the privilege to sell grazing rights to other groups against payment in cash or kind. This is common practice and external users that establish access through payment of grazing fees are dwellers in neighbouring settlements as well as pastoral communities from other areas in North Afghanistan. However, the resident Gujar community whose makeshift huts are scattered above Dara-e Kalan and who as landless people fully depend on the animal husbandry of goat and sheep are granted special status in terms of accessing community pastures. Gujar have made use of their excellent reputation as herdsmen and work as shepherds for villagers. They engage in contractual agreements usually for a six-month period that entails comparatively decent payments in cash plus the right to obtain food and clothes from their employers. As part of these shepherding agreements, they are also allowed to graze their own animals on village pastures. However, there are some restrictions because villagers aim to protect their community pasture from overgrazing and allow only a limited number of additional livestock belonging to Gujar shepherds.

Nonetheless, pastoral activities in Ishkamesh bear some risks, not only because drought conditions put a strain on fodder availability even in the spring season and threaten livestock populations. The violent history of the area both during Soviet occupation and the Taliban reign led to a high occurrence of landmines on the pastures that to date have not been entirely removed. Gujar reported injuries that occurred through the danger of landmines as well as loss of livestock.

Other threats to pastoralism in Ishkamesh refer to the conversion of pastures into rainfed agricultural fields that is triggered by the overall scarcity of productive land in the area. There is some evidence that local farming populations aim to enhance their available land basis for agriculture by converting fertile pasture areas to rainfed cultivation, mostly however on public pastures. According to the director of the Provincial Amlak office (i.e., General Directorate for Land Management that in 2010 was merged into the Afghanistan Land Authority) in Takhar, about 60 per cent of rural households in the entire Takhar province benefit from the conversion of public pasture to rainfed cultivation in order to increase their agricultural basis for food production. ${ }^{7)}$ This widespread practice is highly visible in the rural landscape of Ishkamesh and also attempts to make agricultural use of remote and steep hillsides, thereby abetting soil erosion and degradation. The practice is explicitly prohibited by the pasture law, but the Afghan Government is in no position to enforce the provisions. However, while being aware of the statutes, the formal laws that should govern the pastures remain mere abstractions for affected villagers in Ishkamesh and elsewhere in Takhar when compared to their daily struggle in achieving food security and physical and economic wellbeing (cf. Weinbaum 2007). Consequently, the process of widespread pasture conversion has gradually commenced over the last 20 years or so and has been triggered by population growth and growing food insecurity due to the frequent and often severe droughts. Converted pasture land, however, cannot be used for more than two consecutive years, after which it needs a one year fallow period to recover some of its productivity. It can then be used for low productivity cultivation again, but once converted to rainfed cultivation, it is lost forever as grazing resource.

\footnotetext{
7) Interview from November 8, 2006.
} 
The case of Dara-e Kalan, however, appears to be exceptional with regard to pasture conversion, mainly because of the authority and decision-making capacity of the local community council. Livestock represents a major source of livelihood for many among villagers, and conversion would undermine this reliance on livestock. Apparently, there have been attempts to encroach on village pasture during war times, but a verdict of the local shura forbid any conversion of grasslands for protection of villagebased livestock enterprises.

\section{Different agendas: natural resource man- agement and intergroup relations}

In terms of natural resource management, the practices described above not only determine the forms of use and access to agricultural land and pastures, but also shape intergroup relations, notably between established resident and landed communities and the Gujar as latecomers to Ishkamesh. In a continuum of cooperation and conflict, the Gujar are placed in a marginal position. They provide their expertise and work for mutual benefit as shepherds for village people and spend the entire summer seasons at higher altitudes. However, the Gujar are often blamed for the degradation of natural resources in the area that repeatedly gives rise to conflict situations. This also needs to be seen against the background of the violent past in Ishkamesh and the grievances that arose out of the role of the Gujar as Taliban collaborators. Reasons for environmental concern refer to the common occurrence of fresh wood cutting for heating purposes; a practice that the shura of Dara-e Kalan has explicitly banned, but Gujar apparently do not feel compelled to honour the verdict. Furthermore, the goats kept by Gujar in larger numbers have all but destroyed the occurrence of wild cumin in the mountains that prior to their appearance served as an additional source of income for households in Dara-e Kalan. The location of Gujar hamlets close to the settlement area of Dara-e Kalan also gives rise to resource competition, especially with regard to scarce drinking water. However, Gujar as a marginalised group without access to agricultural lands are bereft of opportunities other than paid shepherding and feel they are unwarrantedly blamed for environmental degradation.

The people of Dara-e Kalan, with the support of an international NGO, have engaged in another resource management project through a pasture enclosure located on a pasture pocket classified as qaumi and in close vicinity to the Gujar hamlets above the village (Photo 1). This same NGO, as the only international aid agency that had worked in the area since the overthrow of the Taliban regime, had before failed in an attempt at reforestation by providing pistachio trees to villagers that had been planted on public lands for common access, but almost all of the seedlings have withered away. Pasture enclosures were another attempt to enhance the natural resource base in Ishkamesh, and villagers themselves raised 40 per cent of the construction costs for a solid stone wall aimed to protect the pasture located on land classified by villagers as qaumi. This money was collected among all households in Dara-e Kalan, making it their own project. People wish to keep the area as communal land that shall be planted with fruit and forest trees and used as common grazing land, all of it under the control of the shura. This is in stark contrast to privatising the enclosure and allocating lands to individual households, which is in fact what the NGO had planned. Such thinking is completely in line with common development policy around pasture enclosures following the worldwide neoliberal trend towards privatisation of public property through fencing of what formerly was common land (TAYLOR 2006). However, enclosures also represent contested spaces, especially over rights of access (RoBbins 1998). As a newly bounded space on what had been common pasturage of Dara-e Kalan before, but with a view of keeping the area common for the own qaum, such conflicts about access arise between different social groupings. Not surprisingly

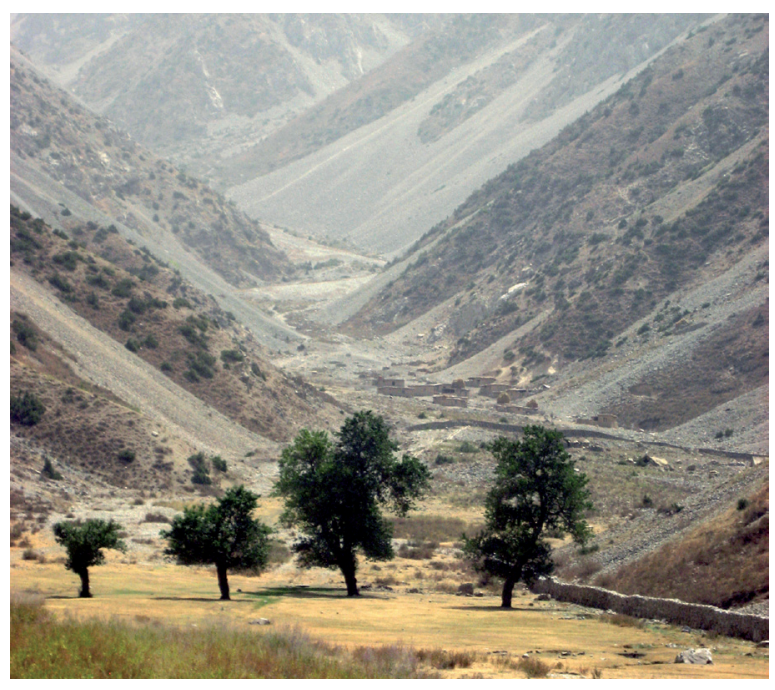

Photo 1: Contested access: pasture enclosure above Dara-e Kalan. A Gujar hamlet is also visible beyond the boundary wall and a Gujar tent camp inside the enclosure. (Photo: SCHÜtTE, September 6, 2008) 
then, new conflicts with Gujar around the enclosure have already emerged, as they do not seem to respect the wall and have erected tents for the summer season inside the enclosure. Gujar also graze goats inside the enclosure, which led to problems with villagers that had established an open tree nursery (Photo 2). Interviewed Gujar reported that they will have vacated the enclosure with the onset of winter and that their goats are never led near the nursery, but that common lands shall also be accessible to them. As such, the erection of a boundary wall has been viewed with suspicion.

Intergroup relations in Dara-e Kalan are thus primarily defined around issues of natural resource management, environmental protection and contractual agreements, while being tainted by a violent past. However, the latent conflicts that exist today are usually settled in a consensual way by means of negotiations between community councils, and existing grievances between communities are mostly put aside for the sake of a peaceful co-existence.

\section{Conclusions}

Pasture management practices and rainfed farming systems as examined through the example of Dara-e Kalan in Ishkamesh resemble shared risk management strategies in the face of multiple uncertainties (cf. Tab. 1). At the same time, these practices provide insights into customary land tenure systems that also provide illustration with regard to the general problems of rural land relations and land security in Afghanistan (cf. Alden Wily 2003; McEwen and WhitTy 2006; MaLETTA 2007). Importantly, pasture management practices and access regimes continue to function without any involvement of the Afghan state or its institutions. The Afghan Land Policy cited above reluctantly acknowledges this fact and addresses widespread pasture degradation as a problem of governance that requires a major policy shift facilitating a transfer of power and responsibilities from central government to communities and enabling people themselves to manage and administer the land they hold and use. Consequently, the land policy asks for more community involvement in land management to be carried out under governmental supervision and guidance. However, it is not clear as to how this may work out in practice. ${ }^{8)}$ Detailed suggestions as

8) Item 2.2.6 of the national land policy states: "It is national policy that access to land resources be clarified and secured as part of an integrated natural resource management

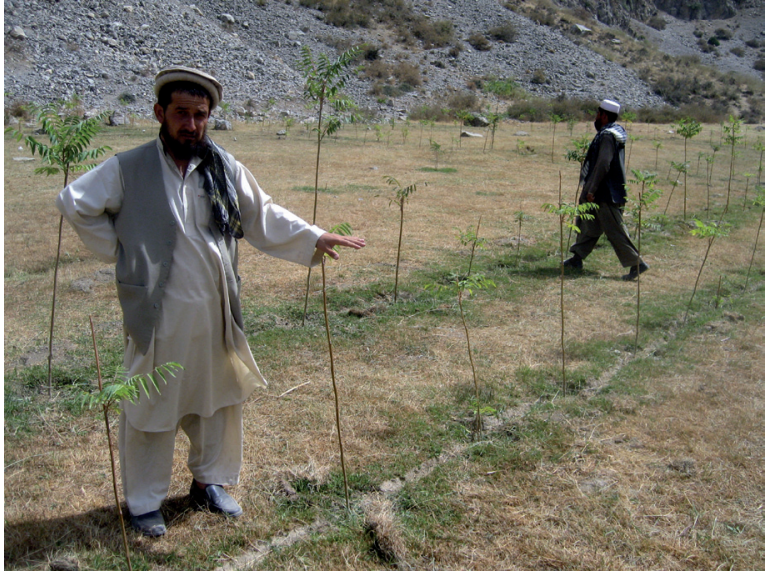

Photo 2: Working in the enclosure: tree nursery maintained by villager of Dara-e Kalan. (Photo: Schütte, September 6, 2008)

to how practical and community-based solutions for the resolution of pasture conflicts and the administration and recording of pasture rights may look like have been put forward but have not been taken up by the Government (cf. ASIAN DEVELOPMENT BANK 2008; Alden WiLy 2009). Such localised approaches to land management involving all potential user groups would build on shared community agreements of access rights to clearly defined areas, as has been presented here in the example of Dara-e Kalan. As a policy move wedded to the idea of decentralisation and devolution of power, those agreements would need to be recorded both at the village level itself and in appropriate governmental agencies. As such, it would aim to integrate local village communities into formal local governance structures by providing them with permanent roles and responsibilities as managers and administrators of defined community pastures (ASIAN DEVELOPMENT BANK 2008). Such policy understanding corresponds to local ideas and practices. Land security is high on the agenda for communities in Ishkamesh who would wish to have their customary pasture rights and boundaries of private agricultural lands secured and certified with appropriate governmental agencies. However, people are aware that the current Afghan Government lacks accountability and administrative capacity and continue to manage their insecure livelihoods with limited external support through functioning community institutions.

which springs from local community based resource management. Such community based resource management must be conducted under the strict supervision and guidance of the Ministry of Agriculture" (GoA 2007). 
In terms of the Afghan insurgency that has gradually spread to the North of the country in the past few years (cf. Giustozzi and Reuter 2011), villagers have felt relatively secure until recently and the Gujar today express no sympathies for the Taliban movement. However, the foreign military presence is perceived as problematic and respondents complained about what is seen as presuming and often impudent meddling in local affairs. Accordingly, the foreign military is increasingly seen as a threat that brings physical insecurity to Ishkamesh, in spite of the Western publicity that claims exactly the opposite. People expressed a clear understanding about the work of the Provincial Reconstruction Teams (cf. STAPLETON 2007) in their area, which is perceived as bringing danger instead of security. This is also why people were seriously concerned when German soldiers arrived at night with about 100 vehicles and erected a field camp in the vicinity of Ishkamesh town in July 2008 and constructed roadblocks and conducted house searches. After two weeks, representatives of many villages requested the Germans to leave, fearing that their continued presence would attract insurgents to carry out attacks, or even worse, encourage insurgent groups to establish a more permanent base in the district. This example quite clearly shows the differing perceptions on what constitutes security and how unpremeditated military presence and activity quite easily leads to the alienation of local populations and involuntarily supports insurgent activities. These worries unfortunately seemed to have been factual, as Ishkamesh today has been identified as one of the few Districts in Takhar with a sizeable Taliban presence (SPECIAL InSPECTOR General for Afghanistan Reconstruction 2012, 113).

In this article findings were synthesised in terms of a human security approach as outlined at the outset of this article by focusing on livelihood security strategies, risk management and conflict resolution practices and the work of social institutions (cf. KREUTZMANN and SCHÜTTE 2012). The case of Ishkamesh provides ample evidence about the shape of 'security strategies' that people in Afghanistan employ to deal with threats, conflicts and livelihood insecurities accruing from local contexts.

\section{Acknowledgements}

The author wishes to thank Paul Smith and Itil Asmon from Mercy Corps for facilitating fieldwork in Ishkamesh, Eng. Akram Salam and his staff from 'Cooperation for Reconstruction of Afghanistan' for supporting the fieldwork, Mohd. Yasin Safar for providing vital guidance and establishing access to Cadastral Survey Data in Taloqan, Kunduz and Kabul, and Haji Jan Mohammad and Maulana Najibullah for introducing us to their village Dara-e Kalan and their invaluable support in facilitating focus group discussions and access to respondents in their own and various other village locales in Ishkamesh District.

\section{References}

AFGHANISTAN HUMAN DEVELOPMENT REPORT (2011): The forgotten front: water security and the crisis in sanitation. Kabul: Centre for Policy and Human Development, Kabul University. www.cphd.af/nhdr/ nhdr2010/AHDR11\%20-\%20Overview.pdf

Akhtar, M.; Ahmad, N. and Booij, M. J. (2008): The impact of climate change on the water resources of Hindukush-Karakorum-Himalaya region under different glacier coverage scenarios. In: Journal of Hydrology 355 (1-4), 148-163. DOI: 10.1016/j.jhydrol.2008.03.015

Alden WiLy, L. (2003): Land rights in crisis. Restoring tenure security in Afghanistan. Kabul.

www. areu.org.af / UpdateDownload Hits. aspx? EditionId=269\&Pdf=302E-Land $\% 20$ Rights $\% 20$ in $\% 20$ Crisis-ES-web.pdf

- (2004) Looking for peace on the pastures. Rural land relations in Afghanistan. Kabul.

www.areu.org.af/EditionDetails.aspx?EditionId=186\& ContentId $=7 \&$ ParentId $=7$

- (2009): Recommended strategy for conflict resolution of competing high pasture claims of settled and nomadic communities in Afghanistan. Kabul.

http://postconflict.unep.ch/publications/afg_tech/ theme_01/afg_rangeland_EN.pdf

ASIAN DEVELOPMENT BANK (2008): Community based approaches for rural land administration and management in Afghanistan. Kabul.

http:/ / trend.ag.utk.edu/AfghanLibrary/nat/RuralLand.pdf

BALland, D. (1988): Nomadic pastoralists and sedentary hosts in the central and western Hindukush mountains, Afghanistan. In: Allan, N. J. R. ; Knapp, G. W. and StADEL, C. (eds.): Human impact on mountains. Totowa NJ, 265-276.

BARFIELD, T. (1978): The impact of Pashtun immigration on nomadic pastoralism in Northeastern Afghanistan. In: Anderson, J. and Strand, R. F. (eds.): Ethnic processes and intergroup relations in contemporary Afghanistan. In: The Afghanistan Council of the Asia Society, Occasional Paper No. 15, 26-34. 
BARTH, F. (1956): Ecologic relationships of ethnic groups in Swat, North Pakistan. In: American Anthropologist 58 (6), 1079-1089. http:/ /www.jstor.org/stable/ 666295

Beath, A.; Christia, F; Enikolopov, R. and Ahmad Kabuli, S. (2010): Randomized impact evaluation of phase-II of Afghanistan's National Solidarity Programme (NSP). Estimates of interim program impact from first followup survey. Kabul.

http://www.3ieimpact.org/en/evidence/impact-evaluations/details/304/

Beebe, S. D. and Kaldor, M. (2010): The ultimate weapon is no weapon. Human security and the new rules of war and peace. New York.

BeEkma, J. and Fiddes, J. (2011): Floods and droughts: the Afghan water paradox. Kabul. www.cphd.af/Downloads/Background\%20Papers/ Flood\%20and \%20drought \%20-\%20The\%20Afghan $\% 20$ water $\% 20$ paradox.pdf

BoHLE, H.-G. (2007): Living with vulnerability. Livelihoods and human security in risky environments 6 . Bonn. www.microinsuranceconference2005.com/dms/MRS/ Documents/InterSection2007_Bohle_Vulnerability.pdf

Dhirendra DatT, D. (1997): State, forests and graziers in the hills of Uttar Pradesh: impact of colonial forestry on peasants, Gujars and Bhotiyas. In: Indian Economic Social History Review 34 (4), 405-435. DOI: 10.1177/001946469703400401

Donini, A. (2007): Local perceptions of assistance to Afghanistan. In: International Peacekeeping 14 (1), 158 172. DOI: $10.1080 / 13533310601114376$

DufFIELD, M. (2001): Global governance and the new wars: the merging of development and security. London.

Ehlers, E. and Kreutzmann, H. (2000): High mountain ecology and economy. Potential and constraints. In: Ehlers, E. and Kreutzmann, H. (eds.): High mountain pastoralism in Northern Pakistan. Stuttgart, 9-36.

Flaming, L. and Roe, A. (2009): Opportunities for pro-poor agricultural growth. Kabul.

http: / / dspace.cigilibrary.org/jspui/bitstream/123456789/24806/1/Opportunities \% 20 for $\% 20$ Pro-Poor $\% 20$ Agricultural $\% 20$ Growth.pdf?1

Gerstle, D. J. (2004): The Pamir paradox: water insecurity and hunger at the source of Central Asia's rivers. In: Journal of International Affairs, 57 (2), 169-178. http:// connection.ebscohost.com/c/articles/15422072/ pamir-paradox-water-insecurity-hunger-source-centralasias-rivers

Giustozzi, A. and Reuter, C. (2011): The insurgents of the Afghan North. The rise of the Taleban, the self-abandonment of the Afghan government and the effects of ISAF's 'capture-and-kill campaign'. Kabul. http://www.afghanistan-analysts.org/publication/theinsurgents-of-the-afghan-north
Glatzer, B.(1981): Processes of nomadization in West Afghanistan. In: Salzman, P. C. (ed.): Contemporary nomadic and pastoral people: Asia and the North. Williamsburg, 61-87.

- (2001): War and boundaries in Afghanistan: significance and relativity of local and social boundaries. In: Die Welt des Islams 41 (3), 379-399. DOI: $10.1163 / 1570060011164891$

GOA (GOVERNMENT OF AFGHANISTAN) (2000): Law on pastures of the Islamic Emirat of Afghanistan. Ministry of Justice, Official Gazette 795. Kabul.

- (2007): Land policy of Afghanistan. Kabul.

GraCE, J. (2004): Gender roles in agriculture. Case studies of five villages in northern Afghanistan. Kabul. www.areu.org.af/Uploads/EditionPdfs / 408E-Gender $\% 20$ Roles $\% 20$ in $\% 20$ Agriculture $\% 20$ CS.pdf

Grace, J. and Pain, A. (2004): Rethinking rural livelihoods in Afghanistan. Kabul. http:/ / areu.org.af/EditionDetails.aspx?EditionId=117 \&ContentId $=7 \&$ Parent $I \mathrm{~d}=7$

Grau, L. W. and Cress, M. A. (eds.) (2002): The Soviet-Afghan war. How a superpower fought and lost. Lawrence.

GrötZBACH, E. (1990): Afghanistan. Eine geographische Landeskunde. Wissenschaftliche Länderkunden 37, Darmstadt.

IRIN (2011): Analysis: Afghan drought conditions could spell disaster. www.irinnews.org/printreport.aspx?reportid=93781

Jentsch, C. (1973): Das Nomadentum in Afghanistan. Eine geographische Untersuchung zu Lebens- und Wirtschaftsformen im asiatischen Trockengebiet. Meisenheim a. Glan.

KING, G. and Murray, C. (2001): Rethinking human security. In: Political Science Quarterly 116 (4), 585-610. DOI: 10.1.1.34.653

KogAN, F. (2002): World droughts in the new millennium from AVHRR-based vegetation health indices. In: EOS, Transactions American Geophysical Union 83 (48), 557-564. DOI: 10.1029/2002EO000382

Kreutzmann, H. and Schütte, S. (2011): Contested commons - multiple insecurities of pastoralists in NorthEastern Afghanistan. In: Erdkunde 65 (2), 99-119. DOI: 10.3112 /erdkunde.2011.02.01

- (2012): Human security, vulnerability and development in Afghanistan. In: Orient 53 (2), 68-75.

Kugbei, S. (2011): Efficiency of wheat seed production and crop diversification in Afghanistan. In: Journal of Crop Improvement 25 (3), 191-201. DOI: 10.1080/15427528.2011.547751

Lautze, S.; Stites, E.; Nojumi, N. and Fazalkarim, N. (2002): Qaht-e-Pool "A cash famine": food insecurity in Afghanistan 1999-2002. Medford.

http:/ /dl.tufts.edu/file_assets/tufts:UA197.012.012.00005 
Maletta, H. (2007): Arable land tenure in Afghanistan in the early post-Taliban era. In: African \& Asian Studies $6(1 / 2)$, 13-52. DOI: $10.1163 / 156921007 \times 180578$

McEwen, A. and WhitTy, B. (2006): Water management, livestock and the opium economy: land tenure. Kabul. www.areu.org.af/Uploads/EditionPdfs/620E-Land\%20 Tenure-CS-print.pdf

Nixon, H. (2008): The changing face of local governance: Community Development Councils in Afghanistan. Kabul. www.areu.org.af/Uploads/EditionPdfs / 802E-Changing $\% 20$ Face $\% 20$ of $\% 20$ local $\% 20$ Governance-WP-print. pdf.pdf

OwEN, T. ( 2003): Measuring human security: overcoming the paradox. Human Security Bulletin, 2 (3). www.taylorowen.com/Articles/2003_Paradox.pdf

PARIS, R. (2001): Human security. Paradigm shift or hot air? In: International Security 26 (2), 87-102. DOI: 10.1162/016228801753191141

Rathjens, C. (1975): Witterungsbedingte Schwankungen der Ernährungsbasis in Afghanistan. In: Erdkunde 29 (3), 182188. DOI: 10.3112 /erdkunde.1975.03.04

RoBBIns, P. (1998): Authority and environment: institutional landscapes in Rajasthan, India. In: Annals of the Association of American Geographers 88 (3), 410-435. DOI: 10.1111/0004-5608.00107

Rockström, J. (2003): Water for food and nature in droughtprone tropics: vapour shift in rainfed agriculture. In: Philosophical Transactions of the Royal Society of London. Series B: Biological Sciences 358 (1440), 1997-2009. DOI: 10.1098/rstb.2003.1400

Roe, A. (2008): Natural resources management, farming systems and rural livelihoods. Kabul.

www.areu.org.af/EditionDetails.aspx?EditionId=498\&Con tentId=7\&ParentId=7

- (2009): Challenges and opportunities for strengthening licit agricultural livelihoods. Kabul.

www.areu.org.af/EditionDetails.aspx?EditionId=229\&Con tentId $=7 \&$ ParentId $=7$

Roy, O. (1989): Afghanistan: back to tribalism or on to Lebanon? In: Third World Quarterly, 11 (4), 70-82. http:/ / www. jstor.org/stable/3992331

- $\left(1990^{2}\right)$ : Islam and resistance in Afghanistan. Cambridge.

Savage, M.; Dougherty, B.; Hamza, M.; Butterfield, R. and Bharwani, S. (2009): Socio-economic impacts of climate change in Afghanistan. Oxford.

SCHÜTte, S. (2012): Pastoralism, power and politics: access to pastures in Northern Afghanistan. In: Kreutzmann, H. (ed.): Pastoral practices in High Asia. Agency of 'development' effected by modernisation, resettlement and transformation. Dordrecht, 53-69. http://link.springer.com/chapt er/10.1007\%2F978-94-007-3846-1_3

SHAHRANI, M. N. (1986): State building and social fragmentation in Afghanistan: a historical perspective. In: BanUazIzI, A and WeIner, M. (eds.): The state, religion, and ethnic politics. Afghanistan, Iran and Pakistan. Syracuse, 23-74.

Special Inspector General for Afghanistan ReconstrucTION (2012): Quarterly report to the United States Congress. Arlington.

Stanfield, D. (2007): Cadastral survey in Afghanistan. Asian Development Bank, Department for International Development: Project Report: Afghanistan Capacity Building for Land Policy and Administration Reform.

Stapleton, B. J. (2007): A means to what end? Why PRTs are peripheral to the bigger political challenges in Afghanistan. In: Journal of Military and Strategic Studies, 10 (1). http://www.jmss.org/jmss/index.php/jmss/article/view/38/36

TAYLOR, J. L. (2006): Negotiating the grassland: the policy of pasture enclosures and contested resource use in Inner Mongolia. In: Human Organization 65 (4), 374-386. http://sfaa.metapress.com/content/43NLYKFU CHG1CBK8

Thomas, V. and Ahmad, M. (2009): A historical perspective on the Mirab System: a case study of the Jangharoq canal, Baghlan. Kabul.

www.areu.org.af/EditionDetails.aspx?EditionId=214\& ContentId=7\&ParentId=7

UNDP (1994): New dimensions of human security. New York, Oxford.

Weinbaum, M. G. (2007): Security in Afghanistan: a historical perspective. In: Danspeckgruber, W. and Finn, R. P. (eds.): Building state and security in Afghanistan. Princeton, 19-35.

Weizman, E. (2011): The least of all possible evils. Humanitarian violence from Arendt to Gaza. London, New York.

Zitelmann, T. (2011): Folgen der Entwicklungshilfe Reloaded: Das Militär in der Arena. In: SchareikA, N. and SpIES, E. (eds.): Auf dem Boden der Tatsachen. Festschrift für Thomas Bierschenk. Köln, 199-216.

\section{Author}

Dr. Stefan Schütte Institute of Geographical Sciences Human Geography Centre for Develeopment Studies Freie Universität Berlin Malteserstr. 74-100 12249 Berlin Germany stefan.schuette@fu-berlin.de 